\title{
PERTANIAN KONVENSIONAL DAN PUPUK ORGANIK : IMPLEMENTASI PROGRAM UNIT PENGOLAH PUPUK ORGANIK (UPPO) DI KELOMPOK TANI SILIH ASIH
}

\author{
CONVENTIONAL AGRICULTURE AND ORGANIC FERTILIZER : \\ IMPLEMENTATION OF THE ORGANIC FERTILIZER PROCESSING UNIT \\ (UPPO) PROGRAM IN SILIH ASIH FARMERS GROUP
}

\author{
Asri Nurrizka Hendarliana*1, Mahra Arari Heryanto ${ }^{2}$, \\ Ronnie Susman Natawidjaja ${ }^{2}$, Pandi Pardian ${ }^{2}$ \\ ${ }^{1}$ Prodi Agribisnis, Fakultas Pertanian, Universitas Padjadjaran \\ ${ }^{2}$ Departemen Sosial Ekonomi Pertanian, Fakultas Pertanian, Universitas Padjadjaran \\ Jl. Raya Bandung Sumedang KM. 21 \\ *E-mail: asri17003@mail.unpad.ac.id \\ (Diterima 18-06-2021; Disetujui 07-07-2021)
}

\begin{abstract}
ABSTRAK
Dampak negatif dari revolusi hijau bagi sektor pertanian salah satunya kerusakan tanah dan meningkatnya populasi hama. Pemerintah mengeluarkan program pertanian organik dengan metode SRI dan UPPO. Kelompok Tani Silih Asih mengimplementasikan pupuk kandang yang dihasilkan dari kegiatan UPPO sebagai upaya pendekatan usahatani padi organik dengan tujuan meningkatkan kegemburan tanah sehingga produktivitas dapat meningkat dan stabil. Namun kegiatan UPPO tersebut tidak berkembang sejak tahun 2016 karena terdapat perubahan pada konsep usaha. Tujuan dari penelitian ini diantara lain: 1) Mengetahui alasan UPPO tidak berkembang, 2) Faktor apa yang mengakibatkan UPPO tidak berkembang. Metode yang digunakan pada penelitian ini adalah metode kualitatif menggunakan pendekatan system thinking dan Participatory Rural Appraisal (PRA). Alat analisis yang digunakan adalah Vensim serta bagan perubahan dan kecenderungan. Hasil dari penelitian ini adalah: 1) UPPO kelompok tani Silih Asih tidak berkembang karena adanya perubahan konsep usaha yang mengakibatkan ternak tidak bertambah, 2) Faktor yang menghambat perkembangan UPPO diantaranya populasi yang berkurang atau tetap, biaya operasional yang terbatas, dan partisipasi anggota yang sedikit.
\end{abstract}

Kata Kunci : UPPO, Konsep Usahatani, Pupuk Kandang

\section{ABSTRACT}

The negative impact of the green revolution for the agriculture sector is soil damageand pest population. The government issued an organic farming program using the SRI and UPPO method. The Silih Asih Farmers Group implements manure pasan effprt to approach organic rice farming with the aim of increase soil looseness so the productivity can increase and be stable. However, UPPO activities have not developed since 2016 due to changes in the business concept applied. The aims of this research include : 1). Knowing the reason UPPO is not growing, 2). What factors caused UPPO not to develop. The method used in this study is a qualitative method using a system thinking and Participatory Rural Appraisal (PRA) approach. The analytical tool usesd is vensim as well as a chart of changes and trends. The results of this study are: 1). UPPO of the Silih Asih farmer group did not develop because of a change in business so that the livestock population did not increase, 2). Factors that may hinder the development of a UPPO include a reduced or fixed population, limited operational cost, and low member participation.

Keywords : UPPO, Farming Concept. Manure 


\section{PENDAHULUAN}

Indonesia meraih swasembada pangan beras pada tahun 1984, dan diraih kembali pada tahun 2008. Hal tersebut terjadi karena adanya revolusi hijau dengan menerapkan berbagai teknologi modern (Las, 2009). Dibalik kesuksesan yang dicapai oleh revolusi hijau terdapat dampak negatif yang diterima oleh sektor pertanian yaitu semakin meluasnya penyebaran hama, ketergantungan dalam menggunakan input kimia berlebihan, lahan menjadi tandus, bahkan petani mengalami gagal panen (Las, 2009; Yulia, 2019).

Dampak negatif tersebut dapat dirasakan ketika revolusi hijau diterapkan dalam jangka panjang yaitu dapat memicu meningkatkan serangan hama karena populasi yang terus meningkat, sehingga sering mengakibatkan para petani mengalami gagal panen. Selain itu, ekosistem tanah mengalami kerusakan, hal tersebut terjadi karena penggunaan input kimia secara berlebihan (Jhamtani, 2008) dalam Heryanto (2016).

Maka dari itu pemerintah mengeluarkan program pertanian organik diantaranya adalah metode SRI (System of Rice Intensification) yang merupakan kegiatan usahatani padi dengan menggunakan teknologi ramah lingkungan, serta penggunaan pupuk dan pestisida organik (Wihastuti, 2017). Metode System of Rice Intensification dilakukan dengan tujuan mengoptimalkan tingkat kesahatan dan produktivitas agroekosistem (Firmanto, 2011). Metode SRI berkembang di berbagai Negara, antara lain Kamboja, Laos, Thailand, Vietnam, Bangladesh, Nepal, Srilanka, Gambia, Madagaskar. Sedangkan di Indonesia metode SRI pertama kali diperkenalkan pada tahun 1997 di Bogor oleh Prof. Norman UPhoff dari Universitas Coenell USA (Gunawan, 2012).

Selain metode SRI, pemerintah memiliki program Unit Pengolah Pupuk Organik (UPPO) dengan tujuan menciptakan petani yang mandiri dalam menyediakan input organik (Dinas Tanaman Pangan dan Hortikultura, 2014). Program UPPO hanya diberikan satu kali kepada setiap kelompok tani, maka dari itu setiap kelompok harus dapat mengembangkan program tersebut agar tetap beroperasi sampai sekarang (Dirjen Tanaman Pangan Kementan, 2018).

Merujuk data Dinas Tanaman Pangan dan Hortikultura Kabupaten Ciamis (2016), Program UPPO di Kabupaten Ciamis dimulai pada tahun 
2016. Program tersebut didorong oleh kebiasaan petani padi yang mulai menggunakan pupuk organik (pupuk kandang dan kompos) sejak tahun 2010. Salah satunya kelompok tani Silih Asih yang berada di Dusun Kaso Kecamatan Cimaragas yang berhasil meningkatkan kesuburan tanah dan produktivitas padi mencapai 6-7 ton/ha.

Walau UPPO beroperasi sejak tahun 2016 sampai sekarang, namun populasi jumlah ternak tidak berkembang, sehingga pupuk kandang yang dihasilkan tidak bertambah sejak awal beroperasi sampai dengan saat ini. Adapun pupuk yang dihasilkan sejak tahun 2016 sampai sekarang hanya mencapai $3.500 \mathrm{~kg} /$ tahun. Kondisi ini menunjukan bahwa kegiatan UPPO tidak berkembang, sedangkan pengguna pupuk kandang terus meningkat.

Berdasarkan uraian di atas, sangat penting untuk meneliti alasan UPPO di kelompok Silih Asih tidak berkembang sedangkan pemakaian dan permintaan pupuk kandang meningkat.

\section{METODE PENELITIAN}

Penelitian ini membahas faktor apa saya yang menghambat perkembangan UPPO kelompok Silih Asih. Penelitian dilakukan di Kelompok Tani Silih Asih pada bulan Januari sampai Mei 2021. Pemilihan lokasi penelitian ditentukan secara sengaja karena UPPO kelompok Silih Asih merupakan program pertama yang dicanangkan di Kecamatan Cimaragas, dan masih beroperasi sampai saat ini; namun tidak mengalami perkembangan sampai dengan saat ini.

Metode penelitian yang digunakan adalah metode kualitatif yaitu eksplorasi suatu masalah atau fenomena di lapangan dengan tahapan pengumpulan dan analisis data dengan teknik wawancara, diskusi kelompok, observasi, dan studi literatur dengan tujuan untuk menggambarkan fenomena yang terjadi sehingga dapat mencapai pemahaman yang mendalam dari fenomena tersebut (Cooper \& Schindler, 2014). Analisis yang digunakan pada metode kualitatif ini adalah system thinking yang merupakan salah satu ilmu yang berhubungan dengan logika dan integrasi disiplin ilmu guna memahami setiap pola dan hubungan masalah yang kompleks (Haraldsson, 2004). Selain itu, menurut Senge (1990 : 68) dalam Mella (2008), system thinking merupakan kerangka kerja yang bertujuan untuk melihat hubungan timbal balik.

Teknik pengumpulan data dilakukan dengan Participatory Rural 
Appraisal (PRA) yang melibatkan partisipasi masyarakat dalam kegiatan pengembangan dan pembangunan masyarakat di daerah (Chambers, 1994). Menurut Lestari (2020), PRA merupakan metode pendekatan penelitian yang menjadikan masyarakat sebagai seorang peneliti, perencana, dan pelaksana dalam suatu kegiatan pemberdayaan. Tujuan utama dari PRA yaitu menganalisis berbagai potensi dan permasalahan yang terdapat dalam suatu daerah sehingga masyarakat dapat membuat perencanaan dan tindakan yang tepat bagi masyarakat di daerah tersebut (Chambers, 1995) dalam Hudayana (2019). Teknik PRA yang digunakan adalah bagan perubahan dan kecenderungan untuk mengetahui pola perilaku sistem terhadap waktu.

Teknik sampling yang digunakan adalah purposive dimana anggota sampel memenuhi kriteria yang telah ditentukan (Cooper \& Schindler, 2014). Kriteria yang dimaksud adalah anggota yang memiliki keterkaitan erat dengan pengelolaan UPPO pada kelompok tani Silih Asih. Jenis data dan teknik pengumpulan data yang digunakan dalam penelitian ini tersaji pada Gambar 1 .

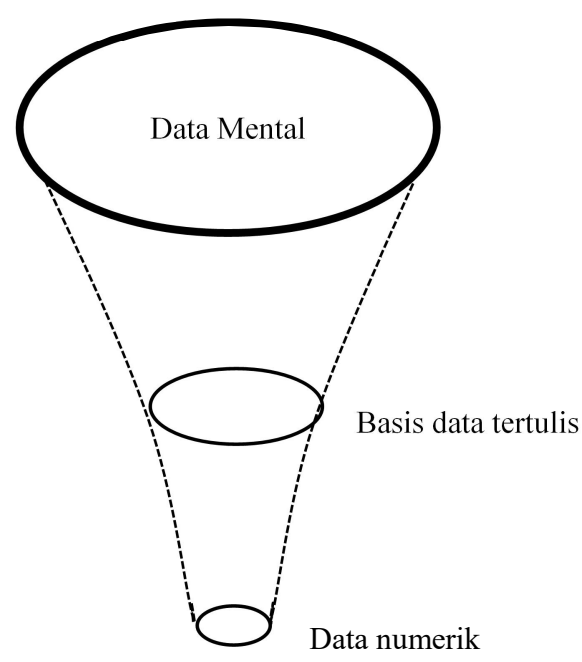

Sumber: Reyes, 2003

Gambar 1. Jenis Data dalam System Thinking \& System Dynamic

Jenis data yang digunakan adalah mental database yang merupakan informasi dan pengalaman yang disampaikan langsung oleh informan. Data mental diperoleh dengan teknik wawancara dan diskusi kelompok melalui PRA. Kemudian written database yang merupakan data hasil wawancara yang telah diolah dalam bentuk transkip wawancara. Data tertulis dapat diperoleh dengan teknik studi literatur. Berikutnya data numerik yang dapat diperoleh secara langsung ketika wawancara ataupun diperoleh melalui lembaga penyedia data dalam bentuk dokumen. ((Reyes, 2003).

Pada analisis data dalam berpikir sistem terdapat beberapa tahapan analisis, yaitu peristiwa, pola perilaku dan struktur sistem (Gambar 2). 


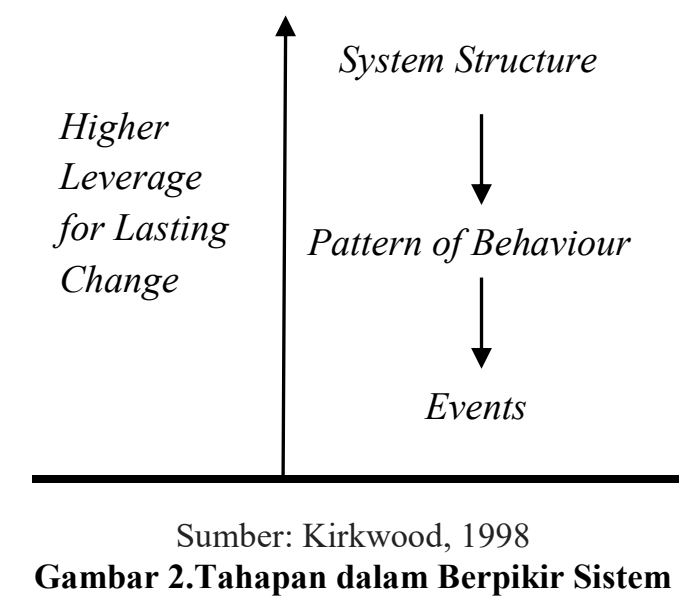

Menurut Kirkwood (1998), semakin ke dalam melihat persoalan (system structure), maka daya ungkit yang dihasilkan semakin tinggi. Artinya, semakin dalam kita melihat persoalan, semakin besar kemampuan untuk melakukan perubahan jangka panjang. Struktur kesisteman (system structure) merupakan rangkaian hubungan sebab akibat yang dapat memunculkan pola perilaku (pattern of behavior) dalam suatu fenomena (events). Selanjutnya menurut Reyes (2003) tahapan analisis system thinking ini merupakan fase awal dari proses pemodelan yang dijelaskan sebagai berikut:

1. Conceptualization, tahapan identifikasi dan mendefinisikan setiap masalah yang ada kemudian melakukan konseptualisasi sistem dengan tujuan menentukan batasan sistem, dan feedback. Pada tahapan ini menggunakan teknik interviews (wawancara), oral history (kajian sejarah), dan focus groups atau diskusi kelompok.

2. Formulation, pada tahap ini dilakukan perumusan dan pembentukan struktur model dari masalah yang diidentifikasi. Pada tahapan ini teknik yang dilakukan adalah wawancara, diskusi grup dan observasi.

\section{HASIL DAN PEMBAHASAN}

\section{Letak Lokasi Penelitian}

Dusun Kaso merupakan salah satu dusun yang berada di Desa Bojongmalang Kecamatan Cimaragas Kabupaten Ciamis. Luas total wilayah Dusun Kaso sekitar 120 hektar, 80\% dari luas wilayah tersebut adalah lahan pertanian khususnya lahan sawah. Berdasarkan pada ketinggian tanah dari permukaan laut Dusun Kaso terletak pada ketinggian 572-700 mdpl. Peta lokasi kelompok tani Silih Asih yag terdapat di Dusun Kaso terlihat pada Gambar 3.

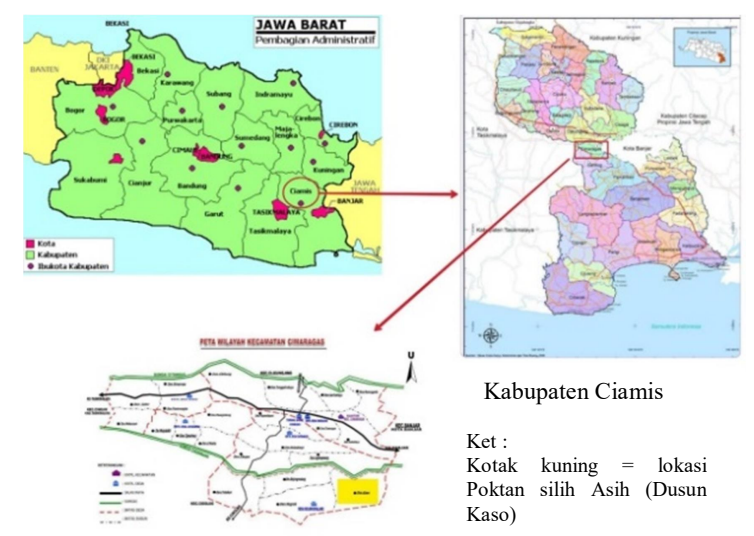

Gambar 3. Lokasi Poktan Silih Asih 
Kelompok Tani Silih Asih berada di Dusun Kaso Desa Bojongmalang Kecamatan Cimaragas Kabupaten Ciamis Provinsi Jawa Barat.

\section{Deskripsi Kelompok Tani Silih Asih}

Kelompok Tani Silih Asih merupakan kelompok hamparan yang terdiri atas empat RT yaitu RT 1, RT 2, RT 3, dan RT 4. Kondisi tersebut menjadikan semua masyarakat pada keempat RT yang bermata pencaharian sebagai petani secara otomatis tergabung sebagai anggota kelompok, namun jumlah anggota terbaru yang tercatat sebagai anggota aktif hanya sebanyak 47 orang.

Kelompok Tani Silih Asih mengaplikasikan program UPPO sebagai pendekatan usahatani padi organik dan hampir semua anggota yang tergabung telah menggunakan pupuk kandang dari UPPO dengan tujuan memperbaiki lahan yang tandus akibat dari pemakaian pupuk kimia secara berlebihan.

Sejak tahun 2010 kelompok Silih Asih telah mengenal sistem usahatani padi organik yaitu dengan menggunakan metode SRI selama 2 tahun, namun metode SRI tidak dapat dilanjutkan karena banyaknya populasi keong di daerah tersebut sehingga kegiatan budidaya tidak dapat dilakukan dengan baik. Maka dari itu metode SRI digantikan dengan pemakaian pupuk organik (pupuk kandang) dengan tujuan untuk memperbaiki tekstur dan kandungan tanah. Selain itu, kelompok tani Silih Asih menjadikan pupuk kandang sebagai metode pendekatan usahatani padi organik sehingga tingkat kebutuhan akan pupuk kandang terus meningkat seperti grafik pada Gambar 4.

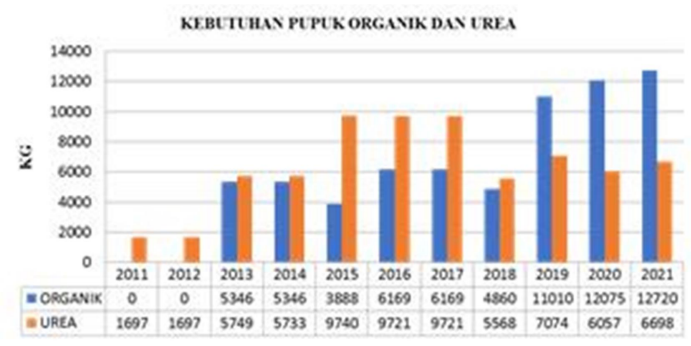

Gambar 4. Kebutuhan Pupuk Organik dan Urea

Gambar 4 menunjukan bahwa kebutuhan akan pupuk kandang di kelompok Silih Asih terus meningkat dan lebih banyak digunakan dibandingkan dengan pupuk urea. Hal tersebut terjadi karena adanya perubahan pada tekstur dan kandungan tanah milik para petani sehingga kegiatan produksi padi dapat dilakukan dengan baik dan produktivitas dapat meningkat secara perlahan serta stabil pada setiap musimnya.

\section{Pola Perubahan Kegiatan Usahatani Setelah Menggunakan Pupuk Kandang dari UPPO}

Berdasarkan hasil wawancara dan diskusi dengan petani yang tergabung dalam Kelompok Silih Asih ditemukan 
beberapa aspek yang mengalami perubahan setelah adanya penggunaan pupuk kandang dalam kegiatan usahatani, sebagai berikut:

a. Kegemburan Tanah

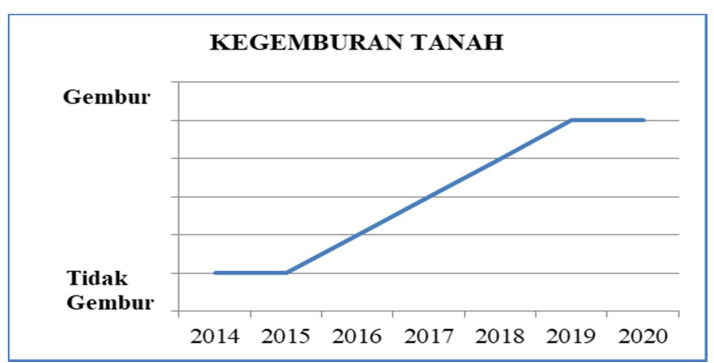

Gambar 5. Kegemburan Tanah

Pada tahun 2014-2015 kondisi tanah lahan sawah milik kelompok Silih Asih termasuk tidak gembur karena akibat dari penggunaan input kimia secara berlebihan. Maka dari itu pada tahun 2016 para petani mulai menggunakan pupuk kandang diikuti dengan pemberian program UPPO sehingga kondisi tanah semakin gembur dan kandungan tanah stabil.

b. Anggota Pengguna Pupuk Kandang

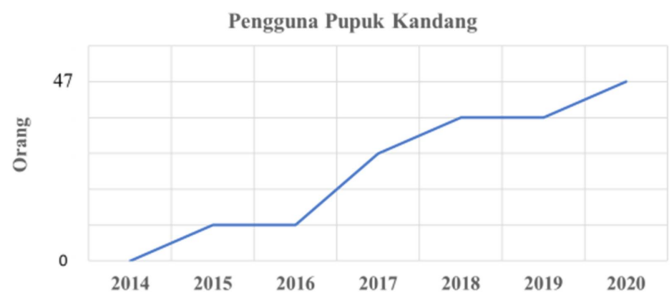

Gambar 6. Pengguna Pupuk Kandang

Pada tahun 2014 anggota kelompok

Silih Asih yang menggunakan pupuk kandang masih sangat sedikit karena adanya ketergantungan dengan pupuk kimia, namun karena kondisi tanah yang semakin tandus dan mudah kering secara perlahan petani mulai menggunakan pupuk kandang terutama sejak tahun 2016 dikarenakan adanya program UPPO yang diberikan oleh pemerintah kepada Poktan Silih Asih sehingga anggota yang menggunakan pupuk kandang terus bertambah sampai sekarang.

c. Waktu Olah Lahan

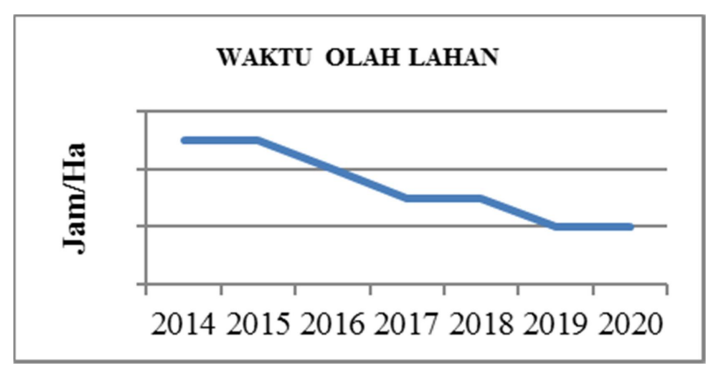

Gambar 7. Waktu Olah Lahan

Waktu pengolahan lahan yang dilakukan oleh petani mengalami perubahan. Pada tahun 2014-2015 waktu yang dibutuhkan untuk mengolah lahan sekitar $49 \mathrm{jam} / \mathrm{ha}$, hal tersebut terjadi karena adanya kesulitan dalam mengolah lahan yang tandus. Namun setelah menggunakan pupuk kandang yaitu sejak tahun 2016 sampai sekarang, waktu yang digunakan untuk mengolah lahan cukup $35 \mathrm{jam} / \mathrm{ha}$ karena kondisi tanah yang cukup gembur sehingga mudah untuk diolah. 
d. Penggunaan Traktor

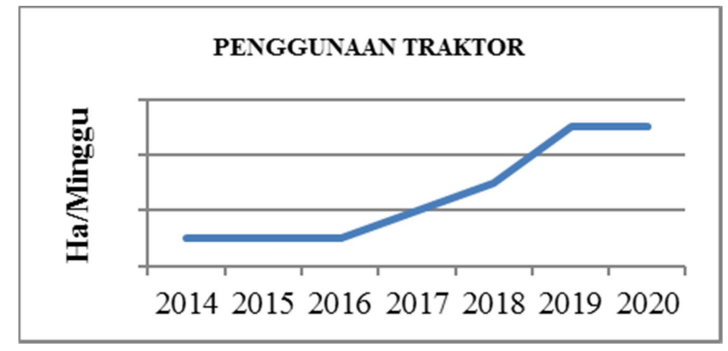

Gambar 8. Penggunaan Traktor

Pada tahun 2014-2016 penggunaan traktor dalam satu minggu untuk mengolah lahan sawah masih sangat sedikit karena perlu waktu yang cukup banyak untuk mengolah 1 ha lahan sawah yang tandus dan kering dengan menggunakan traktor. Sedangkan setelah adanya program UPPO dan para petani menggunakan pupuk kandang yaitu sejak tahun 2017, tingkat penggunaan traktor menjadi bertambah karena kondisi tanah yang gembur mempermudah proses pengolahan lahan dengan menggunakan traktor sehingga dalam satu minggu traktor dapat digunakan pada 2 lahan sawah bahkan lebih.

e. Produktivitas Padi

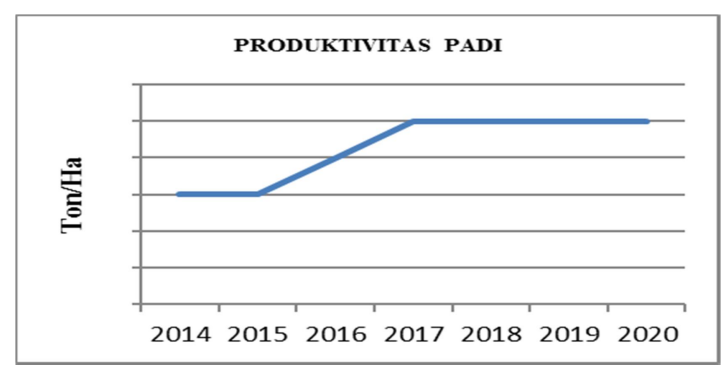

Gambar 9. Produktivitas Padi

Sebelum menggunakan pupuk kandang yaitu pada tahun 2014-2015 produktivitas padi kelompok tani Silih Asih hanya memperoleh 3-4 ton/ha. Kemudian terjadi perubahan produktivitas padi setelah adanya penggunaan pupuk kandang dalam kegiatan usahatani padi mencapai 6-7 ton/ha. Hal tersebut terjadi karena adanya peningkatan kesuburan tanah sehingga nutrisi dan unsur hara yang diperlukan oleh padi terpenuhi dan produktivitas padi yang diperoleh meningkat serta perlahan dan stabil.

f. Produksi Pupuk Kandang UPPO

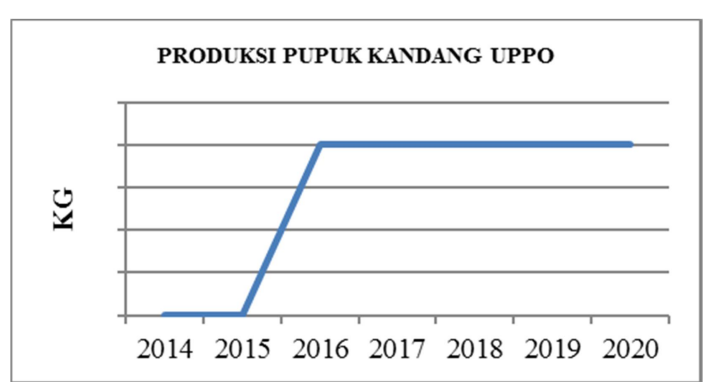

Gambar 10. Produksi Pupuk Kandang UPPO

Produksi pupuk kandang oleh UPPO dilakukan sejak tahun 2016 sampai saat ini. Produksi pupuk dilakukan 2 kali dalam satu tahun karena membutuhkan waktu yang cukup lama pada proses pengeringan pupuk agar memperoleh kualitas yang baik. Pupuk kandang yang dihasilkan sekitar 3.500 $\mathrm{kg} /$ tahun. Jumlah pupuk kandang yang diproduksi oleh UPPO tidak bertambah ataupun berkurang. Dari hasil produksi tersebut dapat memenuhi kebutuhan kelompok sekitar $20 \%$. 
g. Populasi Ternak UPPO

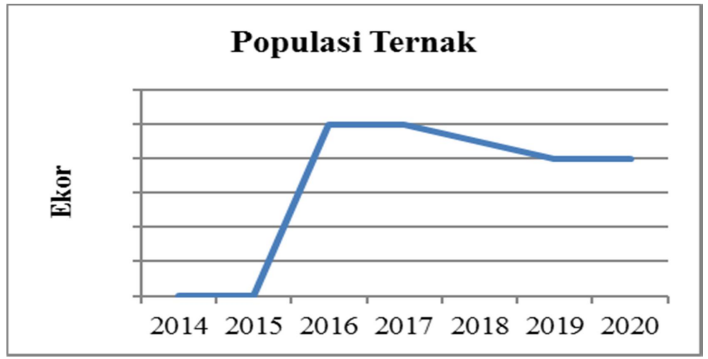

Gambar 11. Populasi Ternak UPPO

Tidak ada peternakan sapi selain ternak millik UPPO di Dusun Kaso. Pada tahun 2016 jumlah ternak yang diberikan dalam program UPPO sebanyak 10 ekor sapi dan berhasil menghasilkan 2 ekor anak sapi pada tahun 2017, tetapi anak sapi tersebut dihibahkan sebagai upah bagi pengurus sehingga populasi tidak bertambah. Di tahun 2018 terdapat 2 ekor sapi mati karena sakit sehingga populasi sapi berkurang menjadi 8 ekor. Pihak pengurus memutuskan untuk menjaga jumlah ternak saat ini yaitu tetap 8 ekor dengan cara menjual sapi dewasa dan membeli sapi muda.

\section{Faktor yang Mendorong Petani Padi Konvensional Menggunakan Pupuk Kandang: Pendekatan Struktu Sistem}

Alasan dan faktor ynag mendorong penggunaan pupuk organik dapat terlihat setelah adanya dampak yang dihasilkan dari pemakaian pupuk kandang yang dirasakan langsung oleh para petani di kelompok tani Silih Asih. Kondisi usahatani padi kelompok tani Silih Asih pada saat menggunakan pupuk kimia terlihat pada Gambar 12.

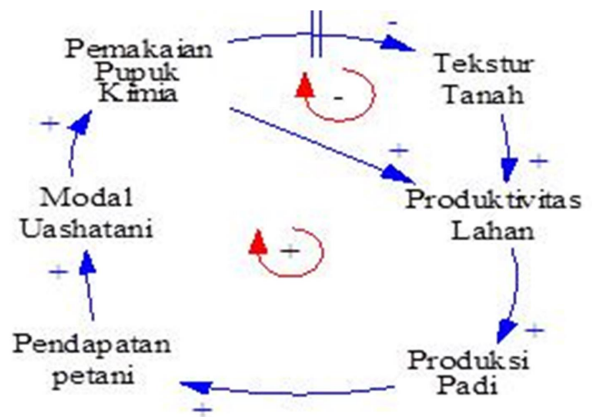

Gambar 12. Struktur Causal Loop Diagram Usahatani Padi Menggunakan Pupuk Kimia

Pada tahun 2014-2015 ketika petani menggunakan pupuk kimia secara berlebihan pada setiap kegiatan budidaya padi menyebabkan kondisi tanah semakin tandus yang berdampak pada kegiatan produksi padi, yaitu kegiatan produksi akan terhambat sehingga tingkat produktivitas padi yang dihasilkan terus berkurang bahkan sampai gagal panen.

Kelompok Tani Silih Asih mendapatkan bantuan program UPPO pada tahun 2016 dan mulai menggunakan pupuk kandang hasil produksi UPPO sejak tahun 2016 sampai sekarang. Setelah menggunakan pupuk kandang pada kegiatan budidaya padi kondisi tanah menjadi gembur dan nutrisi dalam tanah menjadi stabil sehingga kegiatan produksi dapat dilakukan dengan baik dan produktivitas padi yang dihasilkan meningkat sedikit demi sedikit dan dapat stabil sampai saat ini. 


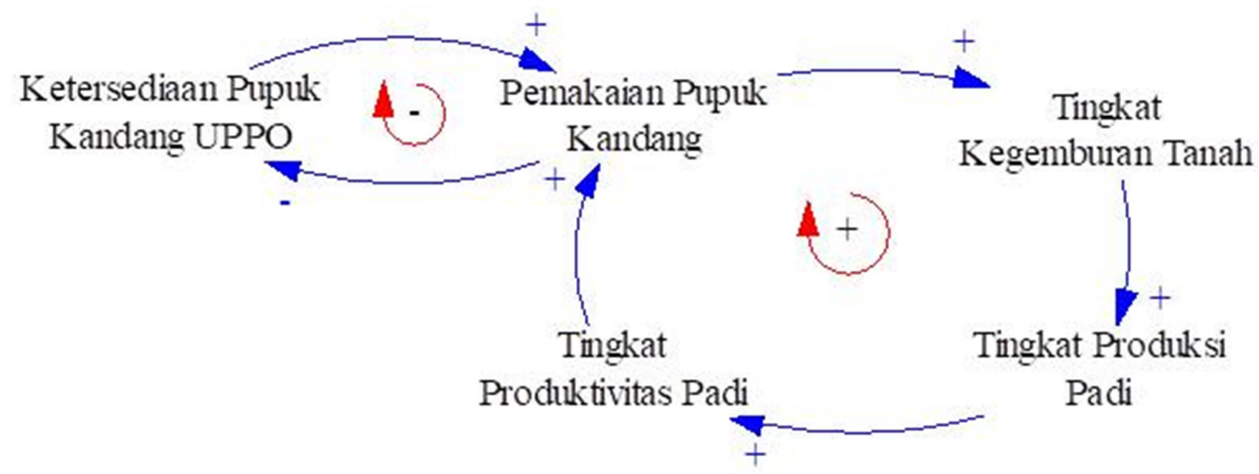

Gambar 13. Struktur Causal Loop Diagram Usahatani Padi Setelah Menggunakan Pupuk Kandang

Dampak dari penggunaan pupuk kandang tidak hanya dirasakan pada kegiatan usahatani padi, tetapi dapat dirasakan perubahannya pada kegiatan pengolahan lahan sebagaimana terlihat pada Gambar 14.

Ketika petani menggunakan pupuk kimia secara berlebihan dalam jangka panjang akan mengakibatkan kondisi tanah menjadi tandus dan tekstur tanah menjadi keras, retak-retak dan cepat kering sehingga sulit untuk melakukan pengolahan lahan. Dengan kondisi tanah yang tandus petani membutuhkan waktu yang cukup lama untuk mengolah lahan menggunakan traktor sampai tanah siap untuk ditanami.

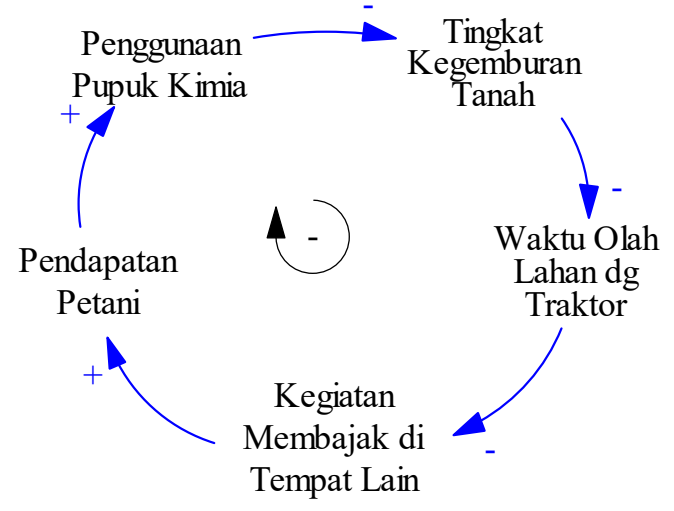

Gambar 14. Struktur Causal Loop Diagram Kegiatan Pengolahan Lahan saat menggunakan Pupuk Kimia

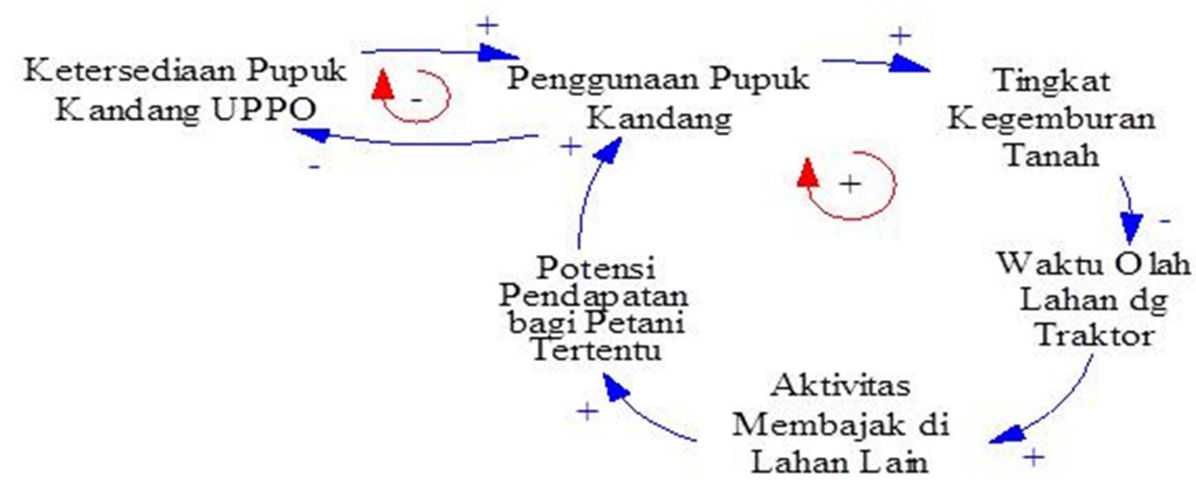

Gambar 15. Struktur Causal Loop Diagram Pengolahan Lahan Setelah Menggunakan Pupuk Kandang 
Sejak tahun 2016 UPPO memproduksi pupuk kandang dan ketersediaan pupuk kandang bagi Poktan Silih Asih dapat terpenuhi secara mandiri sekitar 20\% dari jumlah kebutuhan. Dengan pupuk kandang yang tersesdia dapat meningkatkan penggunaan pupuk kandang sehingga kegemburan tanah meningkat dan stabil. Tanah yang gembur mempermudah pengolahan lahan sehingga waktu yang diperlukan lebih singkat yaitu $35 \mathrm{jam} / \mathrm{ha}$. Pengurangan waktu pengolahan lahan dalam satu minggu dapat meningkatkan penggunaan traktor di lahan petani lain, maka dari itu Hal tersebut dapat mengurangi pendapatan petani.

Mengolah lahan seluas $1 \mathrm{Ha}$ memerlukan waktu $49 \mathrm{jam} / \mathrm{ha}$ sehingga dalam waktu satu minggu kegiatan penggunaan traktor untuk membajak tanah di lahan petani yang lain menjadi berkurang.

Dari struktur di atas didapatkan alasan anggota Poktan Silih Asih menggunakan pupuk kandang adalah karena kondisi tanah yang sebelumnya tandus dan mudah kering menjadi lebih gembur setelah menggunakan pupuk kandang. Faktor yang dapat mendorong penggunaan pupuk kandang adalah adanya pengurangan waktu pengolahan lahan menggunakan traktor serta terdapat potensi pendapatan dari aktivitas membajak lahan petani lain dengan menggunakan traktor. Kemudian tingkat produksi yang secara perlahan meningkat dan tetap stabil.

\section{Faktor Usahatani UPPO di Kelompok Tani Silih Asih Tidak Berkembang: Pendekatan Struktur Sistem}

Dari hasil wawancara, observasi dan diskusi kelompok didapatkan informasi bahwa kegiatan UPPO kelompok tani Silih Asih tidak berkembang sejak tahun 2016 sampai saat ini. Konsep usaha yang diterapkan UPPO pada tahun 2016 adalah pertambahan populasi dimana ketika terdapat anak sapi yang lahir akan dihibahkan kepada pengurus untuk upah mengelola UPPO namun kondisi tersebut tidak memberi keuntungan bagi pengurus karena mengeluarkan tenaga tambahan untuk merawat anak sapi sedangkan upah uang hanya diperoleh dari kegiatan penjualan hasil produksi pupuk kandang dari UPPO yang sedikit sehingga sangat sedikit partisipasi anggota dalam mengelola UPPO. Selain itu, populasi sapi juga tidak bertambah karena adanya hibah anak sapi kepada pengurus UPPO dan terdapat sapi yang mati karena sakit. 
Hal tersebut terjadi karena adanya perubahan konsep usaha yang digunakan oleh kelompok tani. Perubahan konsep usaha UPPO kelompok tani Silih Asih terlihat pada Gambar 16.

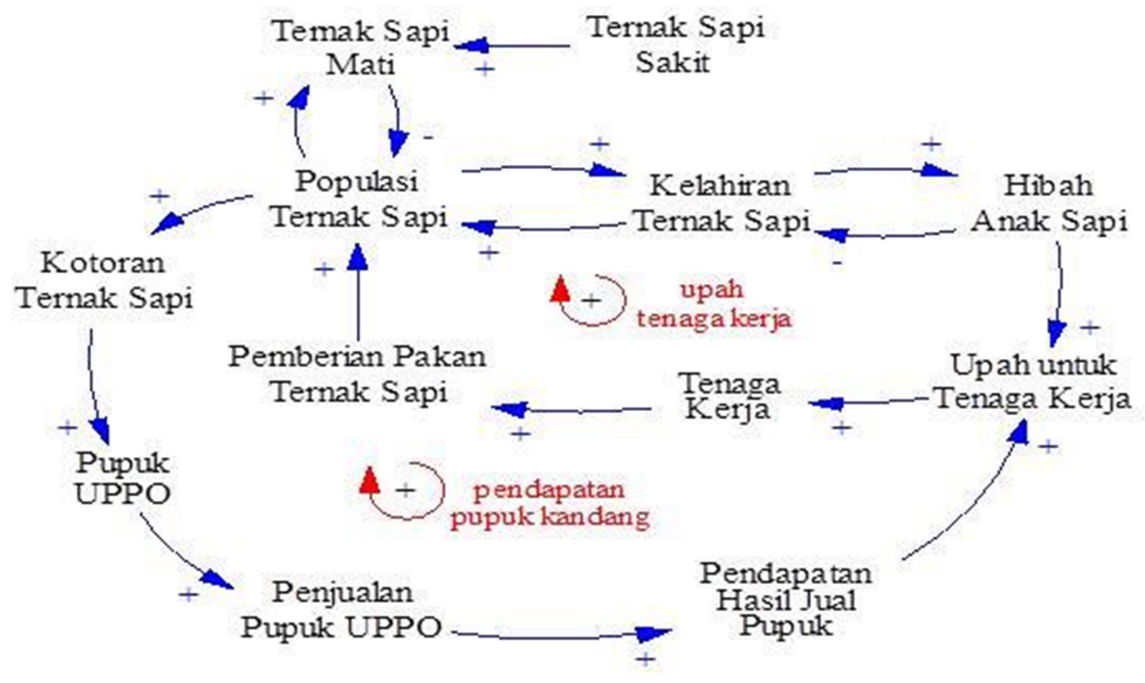

Gambar 16. Struktur Causal Loop Diagram Konsep Usaha UPPO Tahun 2016

Upaya Poktan Silih Asih menerapkan konsep pembesaran ternak mempertahankan kegiatan UPPO mereka sebagaimana terlihat pada Gambar 17.

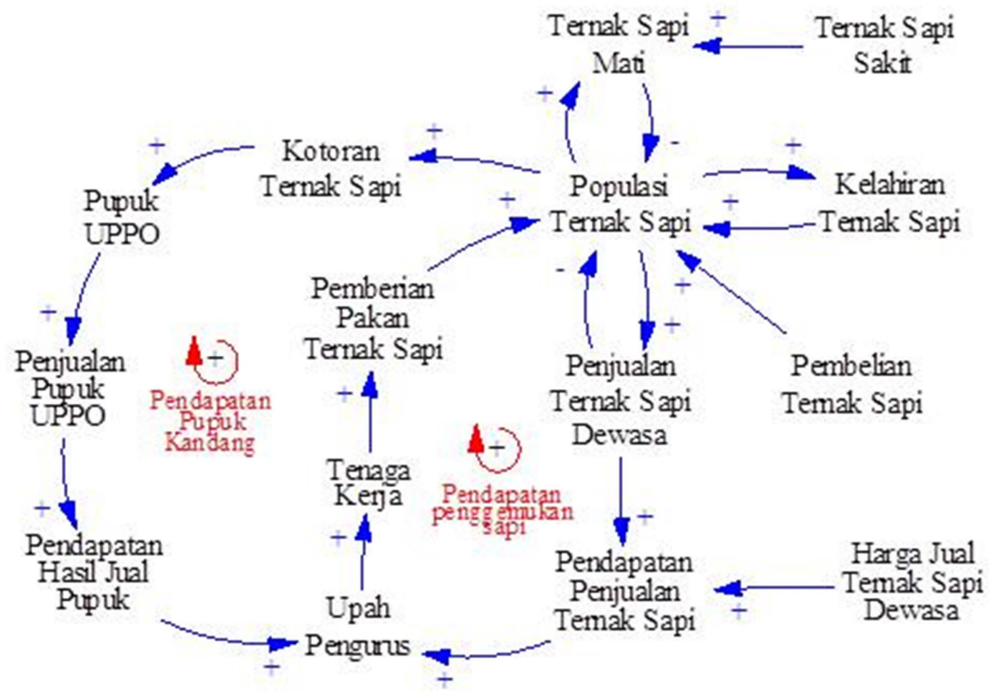

Gambar 17. Struktu Causal Loop Diagram Konsep Pembesaran Ternak UPPO

Pada konsep pembesaran ternak pengurus fokus pada perawatan dan pembesaran ternak sampai dewasa untuk dijual. Dari hasil penjualan sapi dewasa 
digunakan untuk pembelian sapi muda dan membayar upah pengurus. Dengan konsep ini pengurus mendapatkan keuntungan dan tetap bersedia mengelola UPPO sampai sekarang, sedangkan untuk produksi dan penjualan pupuk kandang masih beroperasi dan hasilnya dijadikan tambahan upah dan biaya produksi. Namun dengan konsep pembesaran, populasi tidak akan bertambah karena tujuan kelompok untuk mempertahankan jumlah ternak yang sekarang.

Populasi yang tidak bertambah maka pupuk yang diproduksi tidak akan bertambah sehingga kegiatan usaha UPPO tidak berkembang. Konsep usaha yang seharusnya melakukan pertambahan ternak sehingga produksi pupuk dapat meningkat tidak dilaksanakan dengan baik karena kendala biaya operasional dan upah pengurus sehingga lebih memilih beralih pada konsep pembesaran hewan ternak.

Dari struktur dan penjelasan di atas didapatkan alasan mengapa UPPO milik Poktan Silih Asih tidak berkembang sejak tahun 2016 adalah karena jumlah populasi ternak yang tidak bertambah sehingga bahan baku untuk peroduksi pupuk terbatas maka kuantitas dari pupuk kandang yang dihasilkan tetap sama sejak tahun 2016 sampai saat ini.
Faktor yang dapat menghambat berkembangnya Kegiatan UPPO diantaranya, perubahan konsep usaha yang awalnya pertambahan populasi menjadi perbesaran ternak yang mengakibatkan jumlah ternak tidak bertambah. Kemudian uang kas kelompok yang tidak mencukupi untuk biaya operasional dan upah pengurus UPPO menjadi sebab berubahnya konsep usaha UPPO di Poktan Silih Asih dan kurangnya partisipasi anggota dalam mengelola UPPO.

\section{KESIMPULAN DAN SARAN}

\section{Kesimpulan}

1. Pemakaian pupuk kandang menimbulkan perubahan pada kondisi tanah, produktivitas padi, waktu pengolahan lahan, penggunaan traktor, pengguna pupuk kandang, sedangkan produksi pupuk kandang dan populasi ternak tidak mengalami perubahan.

1. Faktor yang menghambat perkembangan UPPO Kelompok Tani Silih Asih sehingga tidak berkembang adalah karena jumlah ternak yang tidak bertambah sejak tahun" 2016. Perubahan orientasi usaha pengelolaan UPPO dari usaha penyediaan pupuk kandang ke 
penggemukan sapi, uang kas yang tidak mencukupi biaya operasional dan upah pengurus, serta partisipasi anggota yang sangat sedikit merupakan faktor-faktor sebab-akubat yang saling terkait, yang berdampak kepada produksi pupuk kandang tidak bertambah.

\section{Saran}

1. Mengembalikan orientasi usaha UPPO kepada peningkatan populasi sapi guna meningkatkan produksi pupuk kandang bagi anggota kelompok. Sebagai insentif, manajemen pengelolaan UPPO dan mengikutsertakan para anggota dalam kegiatan pengelolaan UPPO yang memberikan keuntungan bagi pengelolanya.

2. Meningkatkan populasi ternak dan bekerja sama dengan dinas peterrnakan dalam pemantauan reproduksi ternak.

3. Melengkapi fasilitas produksi pupuk kandang.

\section{DAFTAR PUSTAKA}

Abdullah, A.H. (2011). Pendekatan Analisis Sistem Causal Loop Diagram (CLD) dalam Memahami Upaya Pemerintah Meningkatkan Akses Masyarakat terhadap Pendidikan Tinggi yang
Berkualitas. Jurnal Ilmiah Iqra', $5(2)$.

Avianto, T.W. at.al. (2017). Development of Spatial-System Dynamics Model for Food Security Policy in Indonesia : AGeneric Sub-Model Simulation. Jurnal Manajemen Teknologi, 16(2), 157-170.

Chambers. R. (1994). The origins and Practice of Participatory Rural Appraisal. World Development, 22(7), 953-969.

Cooper, D.R., \& Scindler.P.S. (2014). Business Research Methods. (12th Editon). Americas : McGrawHill's Primis Online Assets Library Firmanto, B.H. (2011). Sukses Bertanan Padi Secara Organik. Bandung : Angkasa.

Haraldsson, Hordur. V. (2004). Introduction to System Thinking and Causal Loop Diagrams. Departement of Chemical Enginering, Lund University

Heryanto, M.A. dkk. (2016). Model Perilaku Petani dalam Adopsi Sistem Usahatani Padi Organik : Paradoks Sosial-EkonomiLingkungan. Jurnal Sosiohumaniora, 18(2), 159-165.

Hudayana, B. dkk. (2019). Participatory Rural Appraisal (PRA) untuk Pembangunan Desa Wisata di Pedukuhan Pucung,Desa wukisari, Bantul. Jurnal Bakti Budaya, 2(2), 99-112.

Jumna, B.K. (2015). Strategi Pengembangan Usahatani dalam Upaya Peningkatan Produksi Padi Organik. Economics Development Analysis Journal, 4(2), 233-241).

Kirkwood, Craig. W. (1998). System Dynamics Methods : A Quick Introduction. College of Business Arizona State University.

Kuntariningsih, A. at.all. (2014). Adopsi TeknologiPertanian untuk Pembangunan Pedesaan : Sebuah 
Kajian Sosiologis. Agriekonomika, 3(2), 180-191.

Lestari, M.A. dkk. (2020). Penerapan Teknik Participatory Rural Appraisal(PRA) dalam Menangani Permasalahan Sampah. Jurnal Pengabdian dan Penelitian Kepada Masyarakat,1(1), 55-61.

Mella, Piero. (2008). System Thinking : The Art of Understanding th Dynamics of System. The International Journal of Learning. Publisher :http://www:LearningJiurnal.com

Reyes, Luis F L. Andersen, D L. (2003). Collecting and Analyzing Qualitative Data For System Dynamics: Methods and Models. System Dynamics Reviiew. 19(4), 271-296.
Wihastuti, W. at.al. (2017). Analisis Usahatani Padi Organik (Studi Kasus Pada Kelompok Tani Kelapa Herang Di Desa Setiawaras Kecamatan Cibalong Kabupaten Tasikmalaya. Jurnal Ilmiah Mahasiswa AGROINFO GALUH, 4(3), 388-394.

Yulia, D. (2019). Revolusi Hijau Kebijakan Ekonmi Pemerintah Bidang Pertanian di Kanagarian Selayo Thun 1974-1998. Jurnal Program Studi Pendidikan Sejarah, 4 (2), 78-89. 